\title{
Degradation and outflow of amino acids from the rumen of sheep
}

\author{
By D. J. COTTLE* AND W. VELLE† \\ Department of Physiology and Nutrition, Norwegian College of Veterinary Medicine, \\ PO Box 8146 DEP, 0033 Oslo 1, Norway
}

(Received 8 March 1988 - Accepted 14 October 1988)

\begin{abstract}
1. In hay-fed, cannulated sheep the apparent degradation in and outflow from the rumen were determined for graded doses of mixtures of the amino acids lysine, threonine and methionine, administered intraruminally and using polyethylene glycol (PEG) as a liquid marker. The doses ranged between 2.5 and $15 \mathrm{~g}$ for each amino acid in the mixtures.

2. Relative rate of apparent degradation in the first $4 \mathrm{~h}$ was highest for lysine, and lowest for methionine. The apparent degradation in $24 \mathrm{~h}$ was highest for lysine and lowest for threonine. Conversely the fraction flowing out of the rumen in intact form in $24 \mathrm{~h}$ was highest for threonine and lowest for lysine. Rates of apparent degradation as well as outflow were dose-dependent.

3. The validity of the estimated outflow of amino acids from the rumen was corroborated by measurements of concentrations of the amino acids in duodenal contents and in blood plasma which were also dose-dependent.

4. It was concluded that part of the requirement for the essential amino acids threonine and methionine may be met, even when these amino acids are delivered in unprotected form, given as a feed supplement.
\end{abstract}

As all dietary constituents fed to sheep are first subjected to degradation in the rumen and the main limiting nutrients for wool growth are the essential amino acids, it is surprising that there is very little information on the degradabilities in vivo of the individual essential amino acids.

Most of the early work on amino acid degradation has been done in vitro with rumen fluid from cattle (Lewis \& Emery, 1962; Skoch et al. 1975). The few studies done in vivo have produced conflicting information on the relative degradation rates of the important amino acids (Chalupa, 1976). For example the studies of Bird \& Moir (1972), Chalupa (1976), Emery (1971), Langar et al. (1973), suggest that methionine is degraded relatively slowly in the rumen, while the work of Doyle \& Adams (1980), Doyle \& Moir (1979) and Reis et al. (1978), suggests that rapid degradation occurs.

There have been few studies of the effects of dose rate of methionine on subsequent passage of methionine to the duodenum, plasma and wool follicle. Doyle \& Bird (1975) gave varying dietary supplements of methionine to sheep, but each group of sheep fed at a particular level contained different animals. Wool growth was measured, but flow of methionine to the intestines was not assessed.

Doyle \& Adams (1980) found that plasma methionine concentrations did not increase until more than $27 \mathrm{~g}$ methionine were infused intraruminally. However, the degradation rate in the rumen was not measured. There has been some European work done with methionine supplementation, but the experiments have been based on only one dose rate of methionine (e.g. Champredon et al. 1976) or have not monitored the flow of methionine to the intestines (e.g. Vrubcheva, 1984).

Methionine appears to be degraded to a greater extent when given alone rather than in combination with other amino acids (Chalupa, 1976). There have been no studies done in

\footnotetext{
* Present address: Department of Wool Science, Lincoln College, University of Canterbury, Christchurch, New Zealand.

$\dagger$ For reprints.
} 
vivo to determine the optimum combination of amino acids required to achieve the desired flow of undegraded dietary amino acids and microbial protein to the intestines.

The requirements of the sheep for individual amino acids have been studied more extensively (see Buttery \& Foulds, 1985). These studies have normally involved postruminal infusions and hence the modifying influence of the rumen has not been determined (e.g. Brooks et al. 1973, Tao et al. 1974, Downes et al. 1976, Strath \& Shelford, 1978, Mesbah \& Asplund, 1984). There is little information on the optimum ratio of absorbed amino acids for wool growth.

The experiments reported here provide information on the degradation and outflow of methionine, lysine and threonine when given as intrarumen injections.

\section{METHODS \\ Experimental procedure}

Rates in vivo of amino acid metabolism were determined in three sheep with rumen and Tshaped duodenal cannulas. The sheep weighed an average of 87.5 (SE 3.5) $\mathrm{kg}$. They were fed on $1180 \mathrm{~g}$ hay, containing their estimated maintenance energy requirements, once daily, in the morning. Hay of the same batch was used throughout the whole experimental period. Based on the values given in Norwegian feed tables for the type of hay used, the daily ration contained $1 \mathrm{~kg}$ dry matter, $8.81 \mathrm{MJ}$ metabolizable energy, $500 \mathrm{~g}$ nitrogen-free extract, $77 \mathrm{~g}$ ash and $86 \mathrm{~g}$ digestible crude protein. Assuming the rumen-degradable N (RDN) fraction to be $80 \%$, the daily supply of RDN would be $11.0 \mathrm{~g}$ which corresponds closely to the amount recommended by the Agricultural Research Council (1980) at this energy intake. Thus the fermentation of the amino acid doses administered were apparently not limited by the intake of either energy or RDN.

Sheep no. 1 died 2 weeks after Expt 5.

The amino acid mixtures used were prepared in rumen fluid taken from hay-fed sheep, and to the rumen fluid was added $2 \mathrm{~g}$ dioctylsulphosuccinate $/ 1$. On each of the $4 \mathrm{~d}$ before an experiment, and on the experimental day (day 5), the amino acid mixture (Table 1) was administered via the rumen cannula into each sheep at the time of feeding. On the experimental day, the animals were also given $15 \mathrm{~g}$ polyethylene glycol-8000 (PEG) simultaneously via the same route. Rumen and duodenal samples, and blood obtained by venipuncture from the jugular vein, were taken at hourly intervals for $2 \mathrm{~h}$, then every $2 \mathrm{~h}$ for $8 \mathrm{~h}$.

Heparinized blood samples were centrifuged at $10000 \mathrm{~g}$ for $10 \mathrm{~min}$. Plasma, rumen fluid and duodenal fluid samples were deproteinized with $150 \mathrm{~g}$ trichloroacetic acid/1 and centrifuged, and the resultant supernatant fractions stored at $-10^{\circ}$ before analysis. Amino acid concentrations were determined by high-performance liquid chromatography, using the methods described by Bidlingmeyer et al. (1984). PEG was assayed according to the procedure of Smith (1959).

\section{Mathematical procedures}

Rumen fluid pool size and flow rates were calculated from PEG kinetics by fitting a least squares regression to the plot of log PEG concentration $v$. time. Steady state conditions were assumed. Under the conditions of the experiments, non-steady state could not be excluded. Fluid intake might have varied during the sampling periods, although water was available continuously, and the feed intake only represented about $120 \mathrm{~g}$ water. Fluctuations in rumen volume after feeding would change amino acid concentrations which in turn would affect the estimation of degradation rates. However, the $r^{2}$ of the $\ln$ PEG $v$. time regressions were high (over 0.8 ), suggesting limited fluctuations in rumen fluid volume and flow. 
Table 1. Experimental amino acid mixtures $(\mathrm{g} / \mathrm{d})$

\begin{tabular}{ccccc}
\hline \hline Expt no. & Sampling date & Methionine & Lysine & Threonine \\
\hline 1 & $1 / 1 / 1986$ & - & - & - \\
2 & $14 / 1 / 1986$ & 5 & - & - \\
3 & $22 / 1 / 1986$ & 5 & 5 & 5 \\
4 & $29 / 1 / 1986$ & 10 & 10 & 10 \\
5 & $3 / 2 / 1986$ & 15 & 15 & 15 \\
6 & $26 / 2 / 1986$ & 5 & 5 & $2 \cdot 5$ \\
7 & $5 / 3 / 1986$ & $2 \cdot 5$ & 15 & 15 \\
8 & $10 / 3 / 1986$ & 15 & 15 & 15 \\
\hline
\end{tabular}

A microcomputer spreadsheet template using Lotus 123 (Lotus Development Corporation, 1986, Cambridge, Mass., USA) was written to calculate the following.

Amino acid outflow ( $\mu \mathrm{mol} /$ interval) $=$ average amino acid concentration during the interval $(\mu \mathrm{mol} / 1) \times$ fluid flow rate $(1 / \mathrm{min}) \times$ interval $(\mathrm{min})$.

Amino acid degradation $(\mu \mathrm{mol} /$ interval $)=($ start concentration $(\mu \mathrm{mol} / \mathrm{l})-$ end concentration $(\mu \mathrm{mol} / \mathrm{l})) \times$ pool size $(1)$-outflow $(\mu \mathrm{mol})$.

Amino acid concentration at time zero $\left(t_{0}\right)=$ amino dose $(\mu \mathrm{mol}) / \mathrm{pool}$ size (1).

The outflows and degradations of amino acids during the $24 \mathrm{~h}$ following the doses of amino acids were calculated by summing the outflows and degradations calculated for each interval between samplings during this period.

The initial degradation rates of each amino acid were estimated after inspection of the cumulative degradation curves (see Fig. 1). The lysine degradation rates were calculated from the 0-60 min interval. The methionine and threonine degradation rates were calculated from the $0-60,0-120,60-120$ or $60-240 \mathrm{~min}$ intervals. The rates were calculated from the earliest interval possible with positive, linear degradation rates. The $0-60 \mathrm{~min}$ interval was therefore not used for these two amino acids when initial negative degradation values were recorded. Negative values occurred when the amino acid concentrations at 60 min were higher than expected. Poor mixing of the dose or a low estimate of pool size would cause these negative degradation values (see Discussion).

Velocity $\left(V_{\max }\right)$ and Michaelis-Menten constant $\left(K_{M}\right)$ values were calculated by fitting the degradation rates from $60-120 \mathrm{~min}$ to the equation $Y=a+b X$, where $Y$ is $1 /$ degradation rate $(\mu \mathrm{mol} / \mathrm{min}), X$ is $1 /$ substrate concentration at $60 \mathrm{~min}(\mathrm{mmol}), a$ is $1 / V_{\max }$ and $a / b$ is $-1 / K_{M}$. Thus $V_{\max }$ and $K_{M}$ were determined from the Lineweaver Burk plot of degradation rates (Fig. 2).

Differences in mean values were compared by $t$ tests, assuming independent samples.

\section{RESULTS}

Values for the average size of the rumen fluid pool and the liquid flow rate are given in Table 2, together with the effect of the largest doses of amino acid mixtures on these variables. Fluid turnover time was longer in sheep given the largest doses $(P<0.01)$.

The mean cumulative apparent degradation of each amino acid for each dose rate is shown in Fig. 1. The means were calculated by estimating rates within sheep and then calculating the mean and standard deviations.

The calculated rates of apparent degradation $(\mathrm{mmol} / \mathrm{h})$ are given in Table $3 . V_{\max }$ and $K_{M}$ values are presented in Table $4 . V_{\max }$ was converted to $\mathrm{mmol} / \mathrm{h}$ by dividing the estimate from Fig. 2 by pool size ( 9.6 litres); these estimates have large confidence intervals as they are derived from values some distance from the mean substrate concentrations. The $95 \%$ 
Table 2. Pool size, turnover time and flow rate of rumen fluid in hay-fed sheep given intrarumen infusions of graded doses of amino acid mixtures*

(Mean values and standard deviations for animals of body-weight 87.5 (SE 3.5 ) kg)

\begin{tabular}{|c|c|c|c|c|c|c|c|}
\hline & \multirow[b]{2}{*}{$n$} & \multicolumn{2}{|c|}{ Pool size (l) } & \multicolumn{2}{|c|}{ Turnover time (h) } & \multicolumn{2}{|c|}{ Flow rate $(1 / h)$} \\
\hline & & Mean & SD & Mean & SD & Mean & SD \\
\hline Overall means & 18 & $9 \cdot 63$ & 1.085 & $21 \cdot 8$ & 4.09 & 0.45 & 0.071 \\
\hline $\begin{array}{l}\text { Means for low doses of } \\
\text { amino acids }(2 \cdot 5-5 \mathrm{~g})\end{array}$ & 10 & $9 \cdot 49$ & $1 \cdot 309$ & $20 \cdot 3$ & $3 \cdot 40$ & 0.47 & 0.063 \\
\hline $\begin{array}{l}\text { Means for high doses of } \\
\text { amino acids }(10-15 \mathrm{~g})\end{array}$ & 8 & $9 \cdot 80$ & 0.674 & $23 \cdot 7$ & $4 \cdot 07$ & 0.42 & 0.070 \\
\hline
\end{tabular}

- For details of procedure, see p. 398.
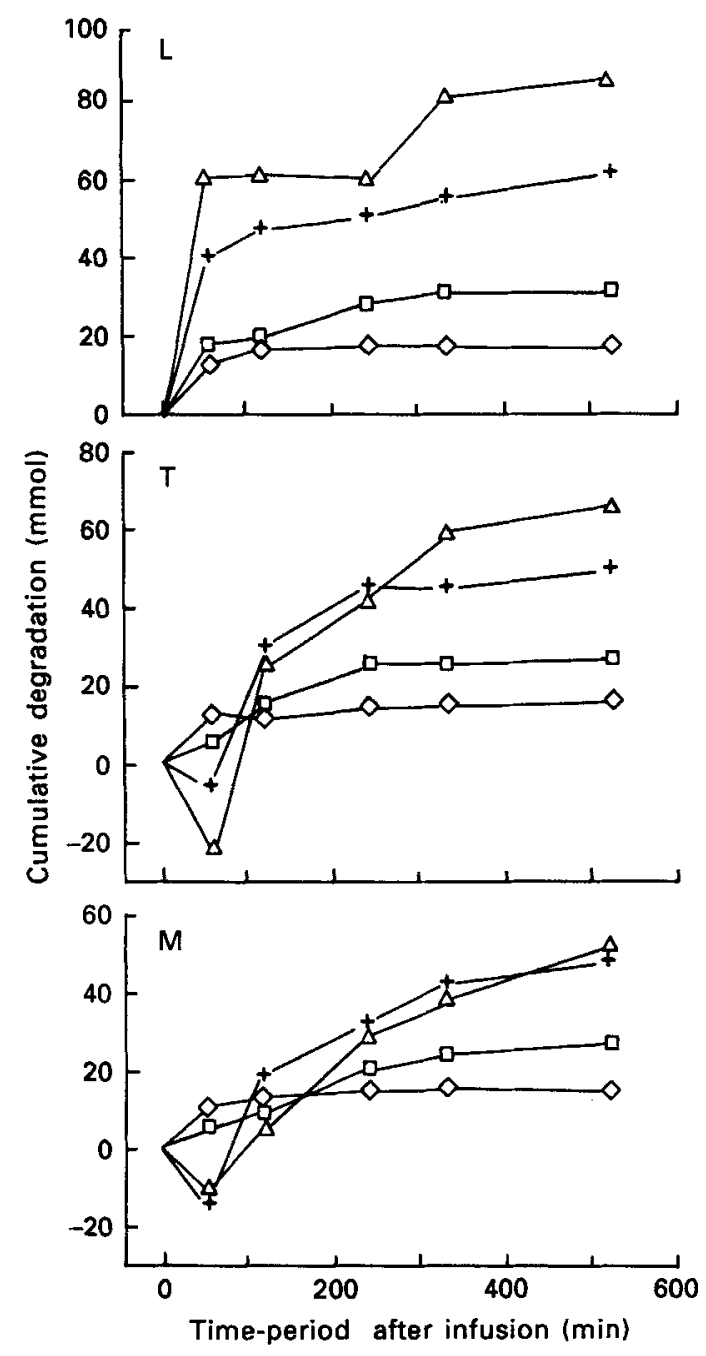
Table 3. Apparent degradation rates ( $\mathrm{mmol} / \mathrm{h}$ and percentage of dose) of amino acids in the rumen of sheep given intrarumen infusions of graded doses of amino acid mixtures*

(Mean values and standard deviations for three sheep in Expts 2-5 and for two sheep in Expts 6-8)

\begin{tabular}{|c|c|c|c|c|c|c|c|c|c|c|c|c|c|}
\hline \multirow{4}{*}{$\begin{array}{c}\text { Expt } \\
\text { no. }\end{array}$} & \multirow{4}{*}{$\begin{array}{l}\text { Dose } \\
\text { of } \\
\text { each } \\
\text { amino } \\
\text { acid } \dagger\end{array}$} & \multicolumn{12}{|c|}{ Rate of apparent degradation } \\
\hline & & \multicolumn{4}{|c|}{ Lysine } & \multicolumn{4}{|c|}{ Threonine } & \multicolumn{4}{|c|}{ Methionine } \\
\hline & & \multicolumn{2}{|c|}{$\mathrm{mmol} / \mathrm{h}$} & \multicolumn{2}{|c|}{$\% / d$} & \multicolumn{2}{|c|}{$\mathrm{mmol} / \mathrm{h}$} & \multicolumn{2}{|c|}{$\% / d$} & \multicolumn{2}{|c|}{$\mathrm{mmol} / \mathrm{h}$} & \multicolumn{2}{|c|}{$\% / d$} \\
\hline & & Mean & SD & Mean & SD & Mean & SD & Mean & SD & Mean & SD & Mean & SD \\
\hline 2 & 5 & - & - & - & - & - & - & - & - & $9 \cdot 1$ & 1.46 & 86 & $2 \cdot 6$ \\
\hline 3 & 5 & $17 \cdot 0$ & 1.79 & 91 & 0.7 & 6.4 & 0.52 & 57 & $8 \cdot 3$ & $8 \cdot 3$ & 1.51 & 83 & 1.4 \\
\hline 4 & 10 & $56 \cdot 8$ & $15 \cdot 10$ & 89 & 3.5 & 19.9 & 3.80 & 62 & 18.9 & $15 \cdot 2$ & $2 \cdot 38$ & 79 & $5 \cdot 2$ \\
\hline 5 & 15 & $65 \cdot 5$ & 8.91 & 86 & $1 \cdot 3$ & $21 \cdot 4$ & $4 \cdot 70$ & 40 & 15.8 & 206 & 0.89 & 70 & $6 \cdot 1$ \\
\hline 7 & $2 \cdot 5$ & $15 \cdot 0$ & $2 \cdot 30$ & 93 & 0.9 & 6.7 & 0.29 & 76 & 1.6 & 6.5 & 0.04 & 88 & $3 \cdot 2$ \\
\hline 6 & 5 & $19 \cdot 1$ & 2.89 & 94 & $1 \cdot 2$ & 130 & $2 \cdot 26$ & 82 & $2 \cdot 8$ & $8 \cdot 9$ & $1 \cdot 36$ & 86 & $4 \cdot 6$ \\
\hline 8 & 15 & $36 \cdot 4$ & 5.94 & 85 & 1.0 & 46.4 & $5 \cdot 40$ & 55 & $8 \cdot 0$ & 26.9 & 9.63 & 82 & 0.4 \\
\hline
\end{tabular}

* For details of procedure, see p. 398

$\dagger$ In each experiment, except Expt 2, the mixture consisted of lysine, threonine and methionine.

Table 4. Kinetics of amino acid degradation in the rumen of hay-fed sheep given intrarumen infusions of graded doses of amino acid mixtures* compared with findings of Chalupa (1976) using cows

\begin{tabular}{lccccc}
\hline \hline & \multicolumn{2}{c}{ Present investigation } & & \multicolumn{2}{c}{ Chalupa (1976) (in vitro) } \\
\cline { 2 - 3 } Amino acid & $\begin{array}{c}V_{\max } \\
(\mathrm{mmol} / \mathrm{l} \text { per h) }\end{array}$ & $\begin{array}{c}K_{M} \\
(\mathrm{mmol} / \mathrm{l})\end{array}$ & & $\begin{array}{c}V_{\max } \\
(\mathrm{mmol} / 1 \mathrm{per} \mathrm{h})\end{array}$ & $\begin{array}{c}K_{M} \\
(\mathrm{mmol} / \mathrm{l})\end{array}$ \\
\hline Lysine & 10.4 & 15.9 & & 0.32 & 0.59 \\
Threonine & 13.9 & 39.5 & 0.50 & 0.81 \\
Methionine & 4.2 & 10.4 & 0.09 & 0.29 \\
\hline \hline
\end{tabular}

$V_{\max }$, velocity; $K_{M}$, Michaelis-Menten constant.

* For details of procedures, see p. 398.

confidence intervals for $1 / V_{\max }(\mathrm{min} / \mu \mathrm{mol})$ were $0.0015 \pm 0.00507,0.0006 \pm 0.00503$ and $0.0004 \pm 0.00532$ for methionine, lysine and threonine respectively. The $95 \%$ confidence intervals for $-1 / K_{M}(1 / \mathrm{mmol})$ were $-0 \cdot 10 \pm 0.321,-0.06 \pm 0.340$ and $-0.03 \pm 0.208$ for methionine, lysine and threonine respectively.

Fig. 3 shows the mean dose-dependent concentrations of lysine, threonine and methionine in rumen fluid, duodenal contents and plasma on day 5, following dosage of the amino acid mixtures in the morning for five consecutive days. As appears from the values, even the pre-dosing concentrations on day 5 were related to the doses administered on the

Fig. 1. Cumulative apparent degradation $v$. time-period after infusion of amino acids in the rumen as a function of dose infused intraruminally. Average of all sheep in all experiments. In all experiments mixtures of equal doses of lysine $(\mathrm{L})$, threonine $(\mathrm{T})$ and methionine $(\mathrm{M})$ were given by intrarumen administration at feeding time in the morning for five consecutive days. Samples collected on day 5 (for details of procedures, see p. 398). $\diamond-\diamond, 2.5 \mathrm{~g} \mathrm{LTM} ; \square-\square, 5 \mathrm{~g} \mathrm{LTM} ;+-+, 10 \mathrm{~g}$ LTM; $\triangle \longrightarrow \triangle 15 \mathrm{~g} \mathrm{LTM}$. 

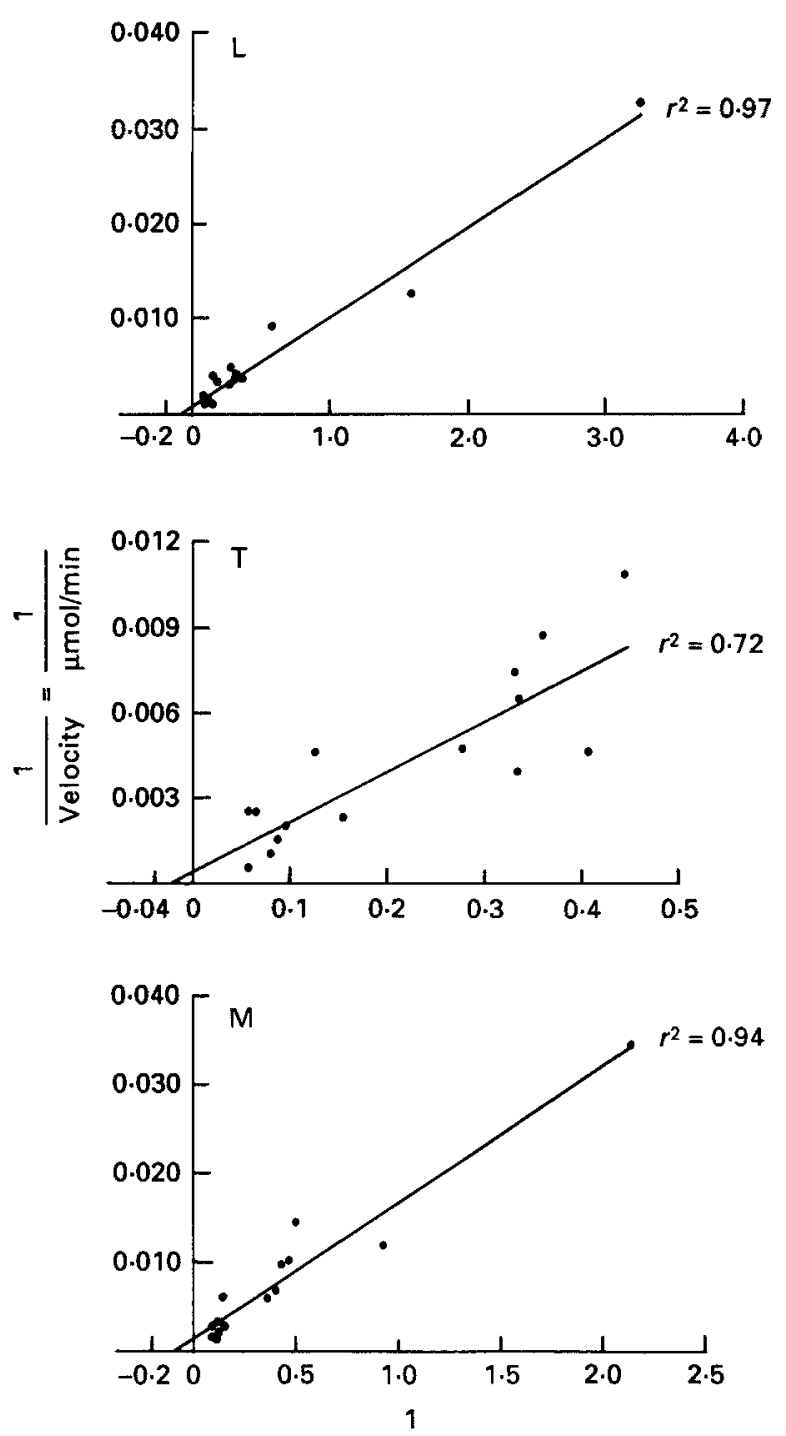

Substrate concentration ( $\mathrm{mmol} / \mathrm{l})$

Fig. 2. Lineweaver-Burk plots of rates of apparent degradation of lysine (L), threonine (T) and methionine (M) as a function of substrate concentration in vivo. Substrate concentrations were calculated on the basis of rumen fluid volume estimated by use of polyethylene glycol as the liquid marker in each experiment (for details of procedures, see p. 398).

four preceding days. This applied to all three fluids examined. The absolute values differed, depending inter alia on the kinetic variables (Tables 3 and 4).

The estimated amounts of each amino acid flowing intact out of the rumen during the first $24 \mathrm{~h}$ after dosing are given in Table 5. The values in Tables 3 and 5 taken together account for total disposal of the offered dose, except for threonine in Expts 5 and 8. In this case, following the initial rapid rates of degradation, a high residual concentration of threonine remained in the rumen $24 \mathrm{~h}$ after dosing.

Table 6 shows the influence of intrarumen injections of mixtures of lysine, threonine and methionine on the concentration of these and some other amino acids in plasma. 


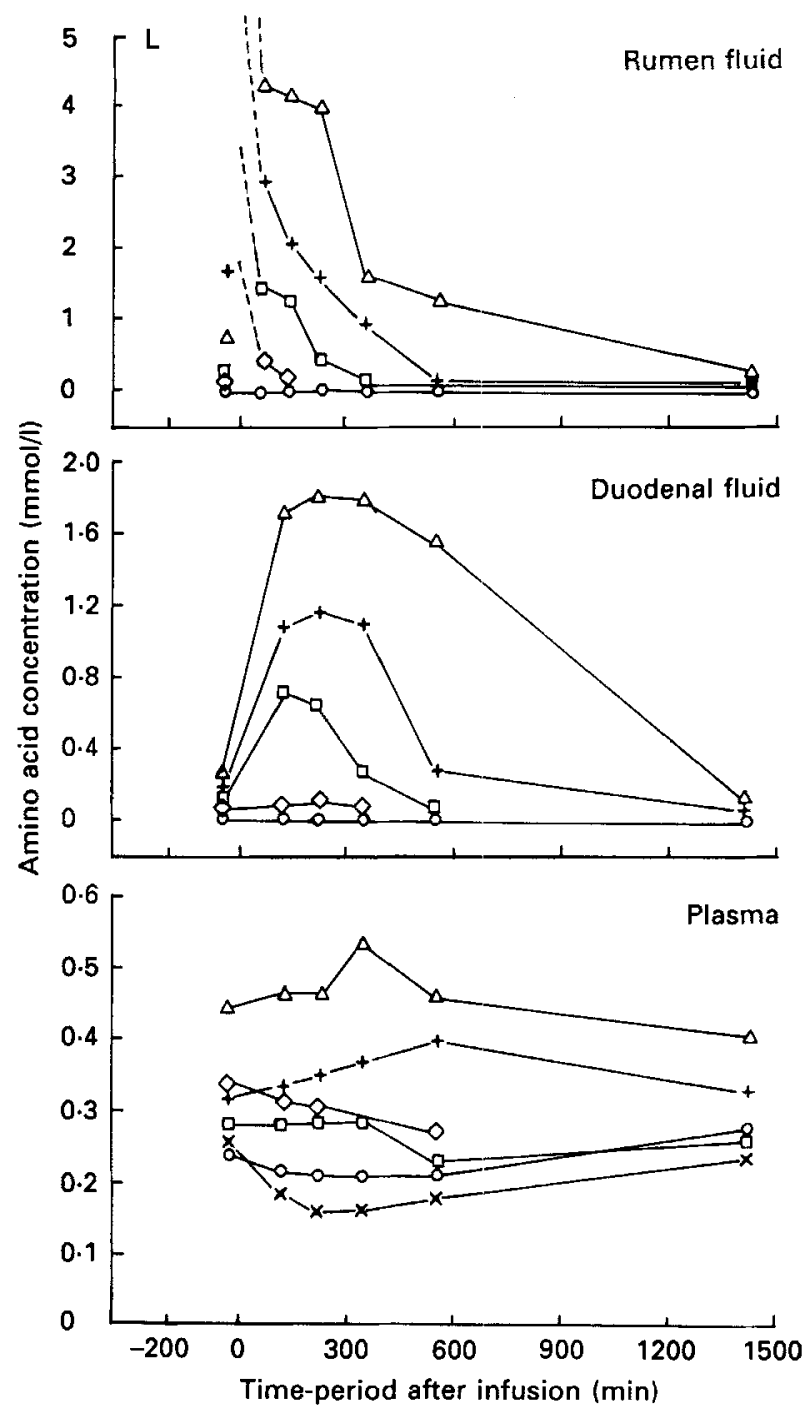

Fig. 3(a).

Fig. 3. Concentration profiles for $(a)$ lysine (L), $(b)$ threonine $(T)$ and $(c)$ methionine $(M)$ in rumen fluid, duodenal fluid and plasma as a function of dose size. In each experiment except one $(x-x)$, mixtures of equal doses of the three amino acids were given by intrarumen administration at feeding time in the morning for five consecutive days. Samples collected on day 5 (for details of procedures, see p. 398). $\mathrm{O}-\mathrm{O}$, Control values; $\diamond-\diamond, 2.5 \mathrm{~g} \mathrm{LTM} ; \times \longrightarrow \times, 5 \mathrm{~g} \mathrm{M} ; \square-\square, 5 \mathrm{gLTM}++\frac{-}{-}$ $10 \mathrm{~g} \mathrm{LTM} ; \triangle-\triangle, 15 \mathrm{~g}$ LTM.

\section{DISCUSSION}

When considering the curves illustrating the cumulative apparent degradation of the three amino acids in the rumen (Fig. 1), some differences between the amino acids were noted. Thus, for lysine the apparent degradation was positive at all dose rates. As for methionine and threonine, the two highest dose rates ( 10 and $15 \mathrm{~g}$ ) apparently caused an initial negative degradation, for which no final explanation has been found. The analytical reliability is high. The most likely errors would be overestimation of pool size, changing pool sizes, 


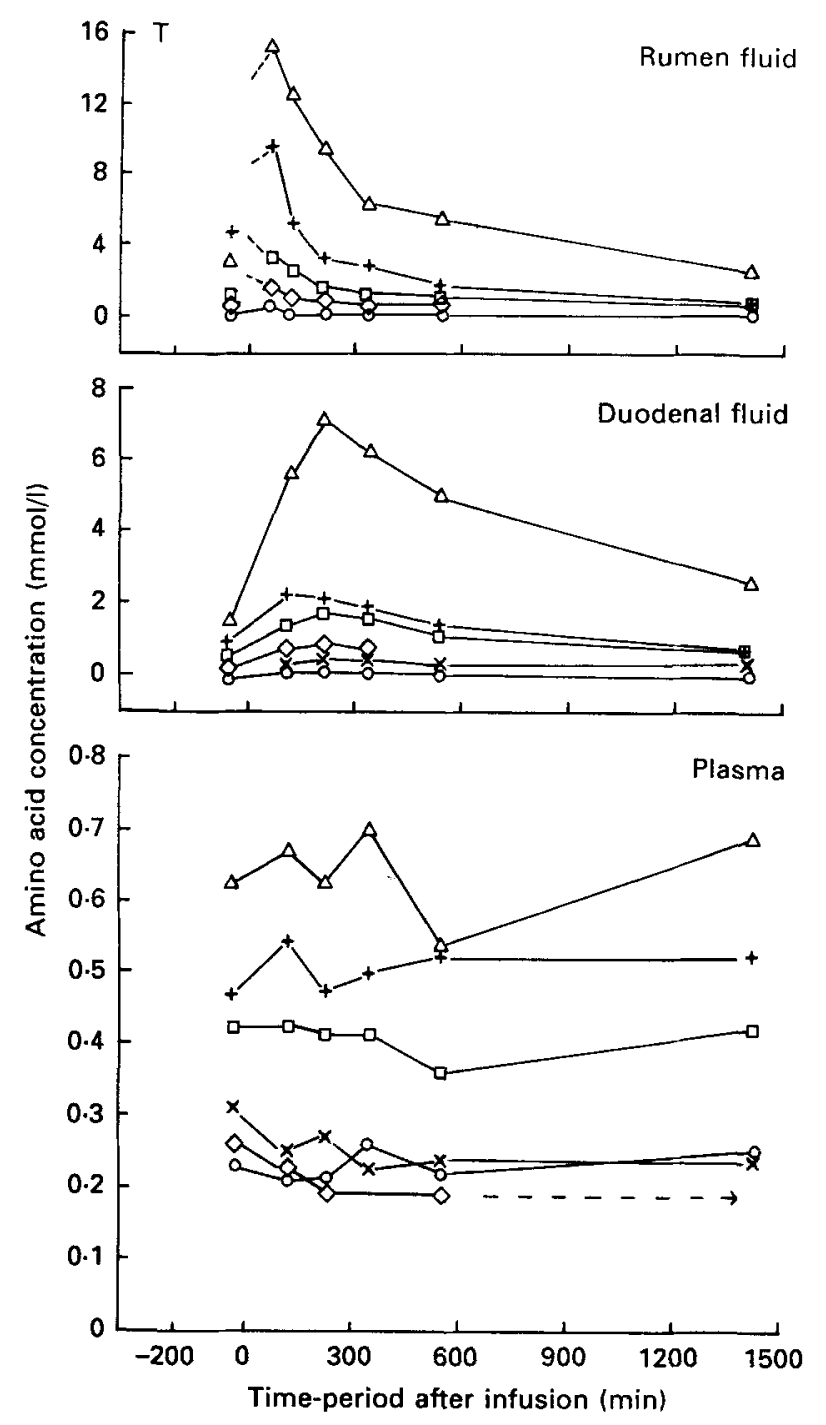

Fig. 3(b).

overestimation of flow rate and poor mixing of large doses of amino acids. Probably the explanation is to be found in the differences in solubility between amino acids. Lysine is extremely water-soluble, whereas methionine and threonine take longer to 'spread' through the rumen fluid. In accordance with this, the concentrations of methionine and threonine were high in the first sample taken at $60 \mathrm{~min}$. Alternatively the initial degradation rate of lysine may also have been underestimated. The uncertainty with respect to the true concentrations at time zero was reduced by calculating degradation rates during the period 60-240 min after administration of the amino acids.

The relative rates of degradation were in general agreement with the findings of Chalupa (1976).

The $V_{\max }$ values obtained in the present study are much higher than those reported by Chalupa (1976) and Skoch et al. (1975). This raises doubts about the validity of extending 


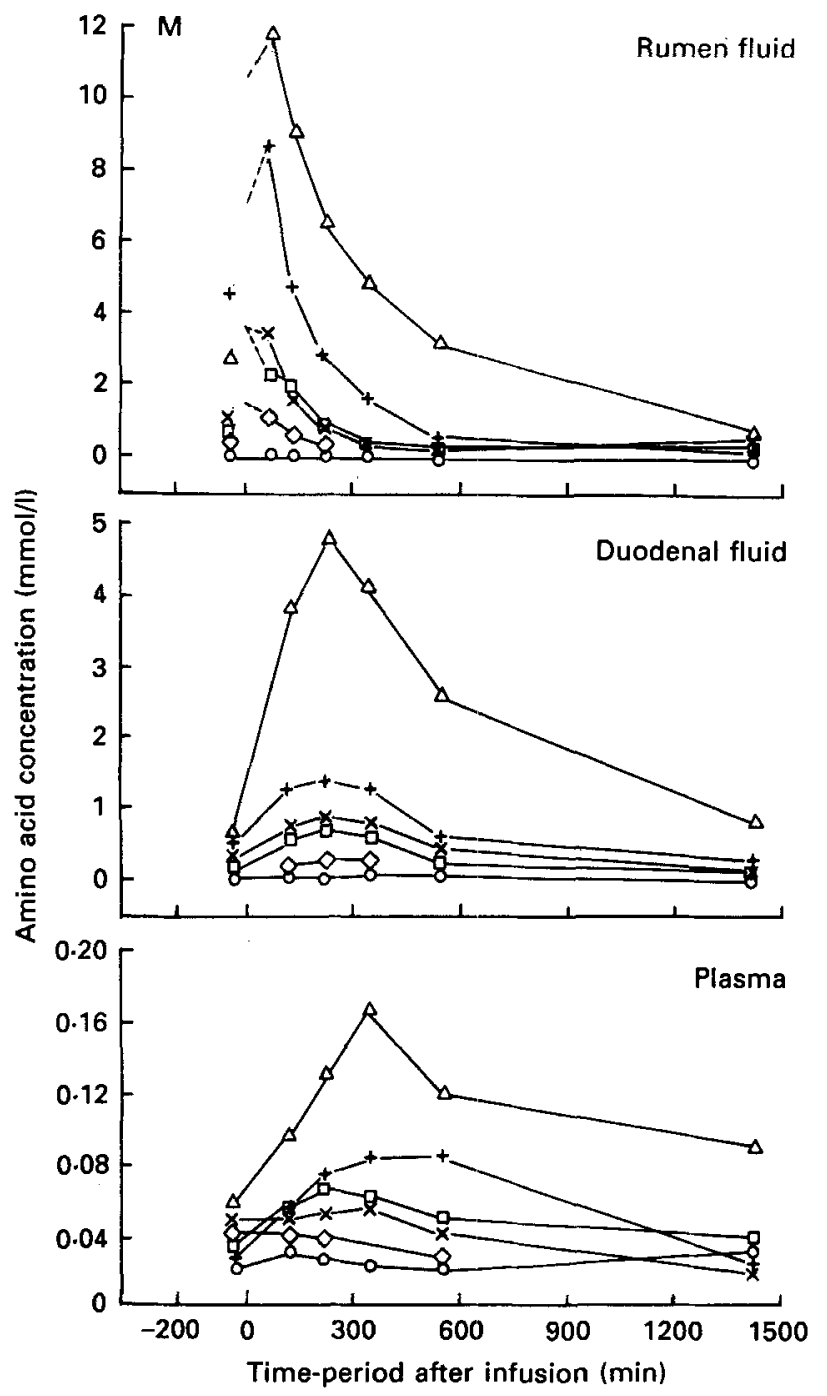

Fig. 3(c).

the previously published in vitro values to the in vivo situation. The degradation rates (mmol/1 per h) obtained in vitro by Chalupa (1976) were much lower than the rates estimated in the present study. For example, at a concentration of $1.7 \mathrm{mmol} / 1(2.5 \mathrm{~g}$ amino acid in rumen), Chalupa (1976) recorded degradation rates in vitro of 0.08 and $0.22 \mathrm{mmol} / 1$ per $\mathrm{h}$ for methionine and lysine respectively, whereas 0.66 and $1.55 \mathrm{mmol} / 1 \mathrm{per} \mathrm{h}$ were the respective rates obtained in the present study in vivo. The $K_{M}$ values found by us $(1.5-4.7 \mathrm{~g} / \mathrm{l})$ are well in excess of normal levels of these amino acids in rumen fluid. Accordingly, degradation of amino acids in the rumen on ordinary diets will be well below $50 \%$ of maximal potential velocity. Therefore degradation rates would be expected to increase substantially when large amounts of amino acids are given.

Unlike the observations made by Chalupa (1976), our results showed a rapid decrease in apparent degradation 1-2 $\mathrm{h}$ after administration of the amino acids as concentrations decreased (see Fig. 1). 
Table 5. Outflow of amino acids from the rumen of hay-fed sheep given intrarumen infusions of graded doses of amino acid mixtures*

(Mean values and standard deviations for three sheep in Expts 3-5 and for two sheep in Expts 6-8)

\begin{tabular}{|c|c|c|c|c|c|c|c|c|c|c|c|c|c|}
\hline \multirow{4}{*}{$\begin{array}{c}\text { Expt } \\
\text { no. }\end{array}$} & \multirow{4}{*}{$\begin{array}{c}\text { Dose } \\
\text { (g) } \\
\text { of } \\
\text { each } \\
\text { amino } \\
\text { acid }\end{array}$} & \multicolumn{12}{|c|}{ Outflow during first $24 \mathrm{~h} \dagger$} \\
\hline & & \multicolumn{4}{|c|}{ Lysine } & \multicolumn{4}{|c|}{ Threonine } & \multicolumn{4}{|c|}{ Methionine } \\
\hline & & \multicolumn{2}{|c|}{ mmol } & \multicolumn{2}{|c|}{$\%$} & \multicolumn{2}{|c|}{ mmol } & \multicolumn{2}{|c|}{$\%$} & \multicolumn{2}{|c|}{ mmol } & \multicolumn{2}{|c|}{$\%$} \\
\hline & & Mean & SD & Mean & SD & Mean & SD & Mean & SD & Mean & SD & Mean & SD \\
\hline 3 & 5 & $3 \cdot 1$ & $0 \cdot 37$ & $9 \cdot 0$ & 1.09 & $14 \cdot 0$ & 1.49 & $33 \cdot 5$ & $3 \cdot 54$ & $5 \cdot 6$ & $0 \cdot 20$ & 16.6 & 0.59 \\
\hline 4 & 10 & $7 \cdot 4$ & $2 \cdot 17$ & $10 \cdot 9$ & $3 \cdot 18$ & $27 \cdot 0$ & $9 \cdot 58$ & $32 \cdot 2$ & $11 \cdot 42$ & $14 \cdot 0$ & $3 \cdot 53$ & $21 \cdot 0$ & $5 \cdot 29$ \\
\hline 5 & 15 & $13 \cdot 4$ & $1 \cdot 14$ & $13 \cdot 1$ & $1 \cdot 11$ & $50 \cdot 0$ & $9 \cdot 73$ & $39 \cdot 7$ & $7 \cdot 73$ & $28 \cdot 4$ & $4 \cdot 59$ & $28 \cdot 5$ & $4 \cdot 61$ \\
\hline 7 & $2 \cdot 5$ & $0 \cdot 7$ & $0 \cdot 23$ & 3.9 & 1.32 & $4 \cdot 8$ & 0.21 & $22 \cdot 6$ & 1.01 & 1.7 & 0.52 & $10 \cdot 3$ & $3 \cdot 12$ \\
\hline 6 & 5 & 1.9 & 0.07 & $5 \cdot 6$ & 0.21 & 7.0 & 0.56 & $16 \cdot 7$ & $1 \cdot 33$ & $3 \cdot 3$ & 0.47 & $9 \cdot 7$ & 1.39 \\
\hline 8 & 15 & $14 \cdot 6$ & 0.42 & 14.2 & 0.41 & $40 \cdot 8$ & 4.76 & 32.4 & 3.78 & $17 \cdot 2$ & $0 \cdot 38$ & $17 \cdot 1$ & 0.38 \\
\hline
\end{tabular}

* For details of procedure, see p. 398. In each experiment the mixture of amino acids consisted of lysine, threonine and methionine.

$\dagger$ Given both in $\mathrm{mmol}$ and in percentage of dose of each amino acid.

Table 6. Effect of intrarumen administration of lysine $(L)$, threonine $(T)$ and methionine $(M)$ on plasma amino acid concentrations of hay-fed sheep

(Mean values and standard deviations of peak values $(\mu \mathrm{mol} / \mathrm{l})$ for three sheep, except for $2.5 \mathrm{~g}$ when only two sheep were used, in control experiments (dose 0 ) and changes in peak values relative to these after graded amounts of amino acid mixtures had been administered)

\begin{tabular}{|c|c|c|c|c|c|c|c|c|c|c|c|c|}
\hline \multirow{2}{*}{$\begin{array}{l}\text { Dose*... } \\
\text { Amino acids } \\
\text { in plasma }\end{array}$} & \multicolumn{2}{|c|}{$\begin{array}{c}\text { Control } \\
0\end{array}$} & \multicolumn{2}{|c|}{$\begin{array}{c}\text { LTM } \\
2 \cdot 5\end{array}$} & \multicolumn{2}{|c|}{$\underset{5 \cdot 0}{\text { LTM }}$} & \multicolumn{2}{|c|}{$\begin{array}{c}\text { LTM } \\
10 \cdot 0\end{array}$} & \multicolumn{2}{|c|}{$\begin{array}{c}\text { LTM } \\
15 \cdot 0\end{array}$} & \multicolumn{2}{|c|}{$\begin{array}{l}M \\
5.0\end{array}$} \\
\hline & Mean & SD & Mean & SD & Mean & SD & Mean & SD & Mean & SD & Mean & SD \\
\hline Lysine & 278 & $18 \cdot 6$ & 69 & $25 \cdot 5$ & 56 & $57 \cdot 2$ & 116 & $57 \cdot 4$ & 261 & $167 \cdot 3$ & -34 & $18 \cdot 6$ \\
\hline Threonine & 262 & $59 \cdot 9$ & -39 & 7.9 & 262 & $47 \cdot 7$ & 284 & 165.6 & 592 & $226 \cdot 4$ & 52 & $92 \cdot 1$ \\
\hline Methionine & 37 & $1 \cdot 3$ & 6 & 0.5 & 31 & $8 \cdot 2$ & 56 & $20 \cdot 4$ & 146 & $80-8$ & 24 & $8 \cdot 5$ \\
\hline Glycine & 1992 & $279 \cdot 1$ & -636 & $207 \cdot 3$ & -630 & $129 \cdot 0$ & -760 & $297 \cdot 0$ & -1121 & $83 \cdot 5$ & \multicolumn{2}{|c|}{$\mathrm{NV}$} \\
\hline Arginine & 310 & $32 \cdot 3$ & -65 & $35 \cdot 1$ & -36 & 14.4 & -72 & $40 \cdot 8$ & -96 & $42 \cdot 0$ & 16 & $18 \cdot 7$ \\
\hline Tyrosine & 79 & 1.5 & -3 & $11 \cdot 8$ & -4 & 143 & -18 & $8 \cdot 1$ & -17 & $8 \cdot 7$ & 7 & $5 \cdot 3$ \\
\hline Valine & 401 & 32.5 & -80 & $15 \cdot 0$ & -78 & $61 \cdot 3$ & -198 & $47 \cdot 0$ & -210 & 31.0 & 31 & $18 \cdot 4$ \\
\hline
\end{tabular}

NV, no value.

* Dose (g) of each amino acid in the mixture.

The degradation of methionine appeared slightly more rapid $(+9 \%)$ and more complete $(+4 \%)$ when given alone than when given together with the two other amino acids. The differences in methionine degradation rates were not significant and were smaller than those found by Chalupa (1976) $(+86 \%)$, but similar to those of Skoch et al. (1975) $(+10 \%)$.

It should be pointed out that fractions of the administered lysine, threonine and methionine probably were incorporated directly into microbial protein. Thus intraruminal degradation may have been slightly overestimated by our method. If this is the case, not only did the animals get the benefit of the fractional outflow of free amino acids, but also of the fractions of the same amino acids carried by microbial protein into the intestine. 
The validity of the estimated outflow of intact amino acids from the rumen (Table 5) was strengthened by the demonstrable dose-dependent increase in the concentrations of the same amino acids in duodenal fluid (Fig. 3).

For cows fed on graded amounts of urea, Broderick et al. (1981) found 7, 16 and $12 \%$ of the requirements for methionine, lysine and threonine could be covered by the passage of rumen free-amino-acids. The requirements of these amino acids in sheep have been estimated by various authors as follows: methionine $(\mathrm{g} / \mathrm{d}): 2.7$ for $32 \mathrm{~kg}$ animals (Strath \& Shelford, 1978), 3.2 for $87 \mathrm{~kg}$ animals (Armstrong \& Annison, 1973), 5.9 for $87 \mathrm{~kg}$ animals (Reis et al. 1978); lysine (g/d): 6.8 for $45 \mathrm{~kg}$ animals (Brooks et al. 1973); threonine (g/d): $9 \cdot 5$ for $87 \mathrm{~kg}$ animals (Armstrong \& Annison, 1973).

It has become conventional to assume that dietary amino acids are extensively degraded in the rumen, such that efforts to balance particular amino acid needs of ruminants would require protection of dietary amino acids from rumen degradation. The present results suggest that important proportions of tissue amino acid needs might possibly be met by giving amino acids in unprotected form. Thus at a dose level of $15 \mathrm{~g}$ amino acid, amounts of $2 \cdot 0,5.6$ and $4.3 \mathrm{~g}$ lysine, threonine and methionine respectively left the rumen in an intact form, representing approximately 30,60 and $70 \%$ of the daily requirements respectively. When $5 \mathrm{~g}$ amino acid were administered, the peak concentration of amino acid in duodenal fluid was increased approximately tenfold relative to the controls (Fig. 3).

Following intrarumen administration of the three amino acids at dose rates of 5,10 and $15 \mathrm{~g} / \mathrm{d}$ for $5 \mathrm{~d}$, the plasma levels of these acids increased rapidly in a dose-dependent manner (Fig. 3 and Table 6). At a $5 \mathrm{~g} / \mathrm{d}$ dose rate, peak plasma amino acid concentrations increased by 23, 64 and 109\% compared with control levels for lysine, threonine and methionine respectively. As regards methionine, Doyle \& Adams (1980), using a continuous intrarumen infusion technique, did not observe any increase in plasma levels above $36 \mu \mathrm{mol} / \mathrm{l}$ until the daily dose was increased to $24 \mathrm{~g}$. The discrepancy between the results of Doyle \& Adams (1980) and the present findings is probably due to the different modes of administration. Continuous infusion undoubtedly facilitates degradation much more than when single doses are administered. Also, contrary to Reis et al. (1978), who did not find an increase in plasma methionine when single doses of $10 \mathrm{~g}$ methionine were given orally, significant increases were observed in our study even at a dose level as low as $5 \mathrm{~g}$.

The fractional outflow from the rumen in $24 \mathrm{~h}$ was much higher for threonine than for the two other amino acids studied. Threonine appeared to be degraded very rapidly for 1-2 $\mathrm{h}$, but had the lowest degradation over the $24 \mathrm{~h}$ period. The reason for this is not known.

Intrarumen amino acid injections seemed to cause a reduction in the concentration of glycine, valine and arginine in plasma (Table 6). Arginine is involved in urea formation. Its plasma level was reduced when lysine and threonine were given. This was not found by Nimrick et al. (1970). Brooks et al. (1973) reported a reduction in the levels of arginine as well as valine in plasma when lysine was abomasally infused in amounts of up to $4 \mathrm{~g} / \mathrm{d}$, but an increase in arginine and valine occurred when doses up to $8 \mathrm{~g} / \mathrm{d}$ were given. Following methionine administration, a reduction in plasma glycine level has previously been reported by S. "ath \& Shelford (1978) and Tao et al. (1974). Glycine is involved in several reactions in which methionine also participates (formation of creatine, cysteine and thereby also glutathione). Administration of methionine may stimulate the biosynthesis of these compounds.

In conclusion our results show that rumen microbes of hay-fed sheep have a high capacity for degradation of unprotected amino acids. Nevertheless, even when given in moderate doses, substantial amounts of the amino acids studied flow out of the rumen in an intact form. Economic comparisons of feeding unprotected $v$. protected amino acids 
should be done on the basis of the cost of providing amino acids to the tissues and the resulting production response. Finally, previous findings of differences between amino acids in rates of apparent degradation were substantiated.

The technical assistance of Dieneke Grønset was greatly appreciated.

\section{REFERENCES}

Agricultural Research Council (1980). The Nutrient Requirements of Ruminant Livestock. Slough: Commonwealth Agricultural Bureaux.

Armstrong, D. G. \& Annison, E. F. (1973). Amino acid requirements and amino acid supply in the sheep. Proceedings of the Nutrition Society 32, 107-113.

Bidlingmeyer, B. A., Tarvin, T. L. \& Cohen, S. A. (1984). Rapid analysis of amino acids using pre-column derivatization. Journal of Chromatography 336, 93-104.

Bird, P. R. \& Moir, R. J. (1972). Sulphur metabolism and excretion studies in ruminants. VIII. Methionine degradation and utilization in sheep when infused into the rumen or abomasum. Australian Journal of Biological Sciences 25, 835-848.

Broderick, G. A., Kang-Meznarich, J. M. \& Craig, W. M. (1981). Total and individual amino acids in strained ruminal liquor from cows fed graded amounts of urea. Journal of Dairy Science 64, 1731-1734.

Brooks, J. M., Owens, F. N., Brown, R. R. \& Carriges, U. S. (1973). Amino acid oxidation and plasma amino acid levels in sheep with abomasal infusions of graded amounts of lysine. Journal of Animal Science 36, 965-970.

Chalupa, W. (1976). Degradation of amino acids by the mixed rumen microbial population. Journal of Animal Science 43, 828-834.

Champredon, C., Pion, R. \& Basson, W. D. (1976). Etude comparé de l'utilisation digestive de la methionine, de son analogue hydroxylé et du sulfate de sodium chez la chévre à laide de composes. Comptes Rendus Hebdomadaires des Seances de l'Academie des Sciences. Ser. D. Sciences naturelles 282, 743-746.

Downes, A. M., Reis, P. J. \& Hensley, J. A. (1976). Proteins and amino acids for wool growth. In Reviews in Rural Sciences, pp. 143-148 [T. M. Sutherland, J. R. Williams and R. A. Leng, editors]. Sydney: U.N.E. Publication Unit.

Doyle, P. T. \& Adams, N. R. (1980). Toxic effects of large amounts of DL-methionine infused into the rumen of sheep. Australian Veterinary Journal 56, 331-334.

Doyle, P. T. \& Bird, P. R. (1975). The influence of dietary supplements of DL-methionine on the growth rate of wool. Australian Journal of Agricultural Research 26, 337-342.

Doyle, P. T. \& Moir, R. J. (1979). Sulfur and methionine metabolism in sheep. III. Excretion and retention of dietary and supplemented sulfur and production responses to intraruminal infusions of DL-methionine. Australian Journal of Agricultural Research 30, 1185-1196.

Emery, R. S. (1971). Disappearance of methionine from the rumen. Journal of Dairy Science 54, $1090-1091$.

Langar, P. N., Buttery, P. J. \& Lewis, D. (1973). N-Steroyl-DL-methionine-a new form of protected methionine for ruminant feeds. Proceedings of the Nutrition Society 32, 86A (Abstr.).

Lewis, T. R. \& Emery, R. S. (1962). Relative deamination rates of amino acids by rumen microorganisms. Journal of Dairy Science 45, 765-768.

Mesbah, M. M. \& Asplund, J. M. (1984). The influence of level of valine on nitrogen status and plasma free amino acid levels in infused sheep. Journal of Nutrition 114, 1363-1369.

Nimrick, K., Hatfield, E. E., Kaninaki, S. \& Owens, F. N. (1970). Quantitative assessment of supplemental amino acid needs for growing lambs fed urea as the sole nitrogen source. Journal of Nutrition 100, 1293-1300.

Reis, P. J., Downes, A. M., Sharry, L. F. \& Tunks, D. A. (1978). Metabolic fate of doses of ${ }^{36}$ S]methionine and $\left[{ }^{35}\right.$ S]cystine in sheep. Proceedings of the Nutrition Society of Australia 3, 75 (Abstr.).

Skoch, G. A., Shellig, G. I., Tucker, R. \& Mitchell, G. E. (1975). Interaction of amino acid degradation by rumen microbes. Journal of Animal Science 40, 197 (Abstr.).

Smith, R. H. (1959). The development and function of the rumen in milk-fed calves. Journal of Agricultural Science, Cambridge 52, 72-78.

Strath, R. A. \& Shelford, J. A. (1978). Abomasal infusion of methionine on plasma amino acid concentration and the uptake of ${ }^{35}$ S-L-methionine in the plasma proteins and urine of growing lambs. Canadian Journal of Animal Science 58, 479-484.

Tao, R. C., Asplund, J. M. \& Kappel, L. C. (1974). Response of nitrogen metabolism, plasma amino acids and insulin levels to various levels of methionine infusion in sheep. Journal of Nutrition 104, 1646-1656.

Vrubcheva, V. (1984). The effect of high amounts of DL-methionine on some biochemical indices of the blood and urine. Veterinaro-Medisinski Nauki 21, no. 6. 4049. 